\title{
Nutritional value and intake of prickly pear by goats
}

\author{
ZENO MCMILLAN, CODY B. SCOTT, CHARLES A. TAYLOR, JR., AND J. ED HUSTON
}

Authors are former Graduate Assistant, Associate Professor, Department of Agriculture, Angelo State University, San Angelo, Tex.; Supervisor, Texas Agricultural Experiment Station, Sonora, Tex; and Professor, Texas Agricultural Experiment Station, San Angelo, Tex.

\begin{abstract}
Prickly pear (Opuntia sp.) is both a benefit and hindrance to the livestock industry in the southwestern U.S. It competes with herbaceous forage but is sometimes used as emergency feed during drought. Spineless prickly pear (O. fiscus-indica Engelm. and $O$. rufida Engelm.) has been planted in some regions of the southwest but little is known about its nutritional value. Our objectives were to determine: (1) the nutritional value of both spined (O. macrorhiza Engelm.) and spineless prickly pear $(O$. rufida Engelm.); (2) if goats can be conditioned to eat prickly pear after prescribed burning; and, (3) if goats would consume prickly pear when alternative forage was available. In Experiment 1, 8 goats were placed in metabolism stalls and fed either spineless or spined prickly pear with singed spines in both summer and winter. Intake, digestibility, and nitrogen balance were measured. In Experiment 2, 18 goats were placed in individual pens, and 9 were fed spineless prickly pear to determine if this increased acceptance of spined prickly pear with singed spines. In the third experiment, we varied the amount of alfalfa pellets fed to goats (below, near, and above maintenance) to determine if level of alfalfa intake affected prickly pear intake. Spineless prickly pear was higher $(P<0.05)$ in digestibility and crude protein than singed prickly pear, but nitrogen balance was similar for goats consuming the 2 species. Goats ate more spineless prickly pear on an as fed basis, but on a dry basis, intake was similar. Familiarity with spineless prickly pear increased $(\mathrm{P}<0.05)$ subsequent intake of singed prickly pear. Level of alfalfa intake did not affect prickly pear intake. We concluded that both species are moderately nutritious, spineless prickly pear is more digestible than spined prickly pear, and once a preference for prickly pear has developed, goats may continue to eat prickly pear even though other forage is available.
\end{abstract}

Key Words: Opuntia, food novelty, learning, diet preference, browsing, protein, nitrogen balance, forage digestibility

The perceived value of prickly pear (Opuntia sp.) varies depending on geographic location and species. Most livestock producers in the southwestern United States attempt to control prickly pear because of its competitive nature with herbaceous forages (Mayeux and Johnson 1989, Ueckert et al. 1988). Most species of prickly pear also contain spines that cause injury to

Funding was provided by the Management, Instruction, and Research Center, Angelo State University, San Angelo, Tex.; Texas Agricultural Experimen Station, Sonora, Tex. The authors would like to acknowledge B.S. Engdahl for her assistance with laboratory analysis.

Manuscript accepted 8 Jul. 01.

\section{Resumen}

El "Prickly pear" (Opuntia sp.) es benéfico pero a la vez también es un estorbo para la ganadería del sudeste de los Estados Unidos. El compite con la vegetación forrajera herbácea, pero en ocasiones es utilizado como forraje de emergencia durante la sequía. En algunas regiones del sudeste se ha plantado una especie de "Prickly pear" sin espinas (O. fiscus-indica Engelm. and $O$. rufida Engelm.), pero poco se sabe acerca de su valor nutricional. Nuestros objetivos fueron determinar (1) el valor nutricional del "Prickly pear" con espinas $(O$. macrorhiza Engelm.) y sin espinas (O. rufida Engelm.); (2) si las cabras pueden ser acondicionadas para comer "Prickly pear" después de un fuego prescrito y (3) si las cabras consumirían "Prickly pear" cuando otro forraje alternativo esta disponible. En el experimento 1,8 cabras se colocaron en jaulas metabólicas individuales y durante el invierno y verano fueron alimentadas con "Prickly pear"sin espinas o con espinas marcadas y se midió el consumo, la digestibilidad y el balance de nitrógeno. En el experimento 2, 18 cabras fueron colocadas en corrales individuales y 9 se alimentaron con "Prickly pear" sin espinas para determinar si esto incrementa la aceptación sobre el "Prickly pear" con espinas marcadas. En el tercer experimento variamos la cantidad de pelets de alfalfa con la que se alimento a las cabras (abajo, cerca y arriba del nivel de mantenimiento) para determinar si el nivel de consumo de alfalfa afectó el consumo de "Prickly pear". La especie de "Prickly pear" sin espinas fue mayor en digestibilidad y proteína cruda $(P<0.05)$ que la especie con espinas marcadas, pero el balance de nitrógeno fue similar en cabras consumiendo las 2 especies. En base al alimento, las cabras consumieron mas "Prickly pear" sin espinas, pero en base de materia seca el consumo fue similar. La familiaridad del "Prickly pear" sin espinas incremento $(P<0.05)$ el consumo subsecuente de "Prickly pear" con espinas marcadas. El nivel de consumo de alfalfa no afecto el consumo de "Prickly pear". Concluimos que ambas especies son moderadamente nutritivas, que el "Prickly pear" sin espinas es mas digestible que la especie con espinas y que una vez que la preferencia por "Prickly pear" ha sido desarrollada las cabras pueden continuar comiendo “Prickly pear" aunque otro forraje este disponible.

livestock after ingestion (Ueckert et al. 1990). In other areas, spineless prickly pear (Opuntia fiscus-indica Engelm. and $O$. ficus-indica (L.) Miller) has been introduced as an alternative feed (Brutsch and Zimmerman 1993). Spined prickly pear is used as forage for livestock, especially during droughts (Griffiths 1905, Bement 1969, Lehman 1969, Hanselka and Paschal 1991). Before feeding or grazing prickly pear, the pads are generally singed with a propane burner to remove the spines thereby improving acceptance and reducing the health hazards (i.e., phys- 
ical damage to the lips, mouth, and upper gastrointestinal tract) (Ueckert et al. 1990, Hanselka et al. 1993).

Throughout most of western and central Texas, prescribed burning is used to reduce prickly pear abundance, but mortality rates are low unless winter burning is followed with herbicide application (Ueckert 1997, Ueckert et al. 1988). The high cost of herbicides limits the economic feasibility of controlling prickly pear. Given that livestock will consume prickly pear after the spines have been removed, prescribed burning could be followed by livestock grazing. Grazing after burning may also reduce prickly pear density because the plant does not tolerate heavy defoliation (Maltsberger 1989).

Prickly pear species are common throughout the southwestern U.S. and many produce substantial phytomass that can serve as emergency forage (Garcia de Cortazar and Nobel 1992). Prickly pear is moderately high in sugars, starch, ether extract, crude protein, amino acids, and fiber (Teles et al. 1984, Retamal et al. 1987). However, the availability of nutrients for ruminant animals has not been assessed. To assess the potential value of singing prickly pear as an emergency forage resource, it is important to know its forage value. Thus, the first objective of this study was to quantify in vivo digestibility of prickly pear and nitrogen balance of goats consuming prickly pear.

Our second objective was to determine if we could improve acceptance of prickly pear as a forage. Recent studies on livestock training have suggested that previous experiences with certain foods increases intake, and preferences may develop and persist (Provenza 1994). Thus, it may be possible to train livestock to consume more prickly pear, thereby increasing the effectiveness of livestock herbivory after prescribed burning as a biological control. We hypothesized that feeding spineless prickly pear immediately after weaning would improve acceptance of singed (spined) prickly pear.

Given the presence of spines, livestock generally avoid eating prickly pear when other forage is available. However, livestock have been observed to eat prickly pear throughout the year even though they develop health problems and alternative forage is available (Hanselka et al. 1993). Our third objective was to determine how dietary feed level affected intake of prickly pear by goats. We hypothesized that goats meeting or exceeding maintenance requirements would avoid eating prickly pear while goats unable to meet mainte- nance requirements because of limited feed intake would consume prickly pear.

\section{Methods}

All experiments were conducted at the Texas Agricultural Experiment Station, Sonora, Tex. $\left(30^{\circ} \mathrm{N}, 100^{\circ} \mathrm{W}\right)$ beginning in June 1999. Spined (O. macrohiza Engelm.) and spineless ( $O$. rufida Engelm.) prickly pear were fed to goats in 3 studies. The spineless prickly pear was grown on site under ambient conditions, and the spined prickly pear was harvested from a natural stand nearby. The spined prickly pear was singed with a propane burner in the field each day immediately before harvesting to remove all spines. Both types of prickly pear were cut into 5 $\mathrm{cm}$ wide strips, and fed fresh to individual goats in each of the 3 experiments.

\section{Metabolism Study}

Eight female Boer-Spanish cross goats (11 months-old and weighing about $45 \mathrm{~kg}$ ) were randomly allocated to 1 of 2 treatments in a Latin square design. Goats were housed in an open-air building in individual $2.4 \times 1.1 \times 1.7 \mathrm{~m}$ metabolism stalls with expanded steel floors to allow feces and urine separation and collection. Goats were given ad libitum access to either spined prickly pear with singed spines or spineless prickly pear daily. Intake, fecal output and urine output were recorded daily. All goats used in this study were accustomed to the stalls from a previous experiment.

Treatments consisted of feeding either singed or spineless prickly pear to individual goats ( 8 goats/treatment). Two periods were conducted with treatments reversed (i.e., 4 goats fed spineless prickly pear in Period 1 were fed singed prickly pear in Period 2). Period 2 was initiated 10 days after the completion of Period 1. Goats were maintained on alfalfa pellets (15 $\mathrm{g}$ $\mathrm{kg}^{-1}$ ) between periods. Goats were fed the appropriate prickly pear during a 3-day adjustment period followed by a 5-day collection period. Relatively short adjustment and collections periods were used because of the short retention time of goats (Huston et al. 1986). A 2 × 2 Latin square design was used for Experiment 1 because of a limited number of metabolism stalls.

Feces and urine were collected daily during each 5-day collection period for each trial. Ten $\mathrm{ml}$ of $25 \% \mathrm{H}_{2} \mathrm{SO}_{4}$ was added to 1-gallon plastic collection containers to prevent volatilization of ammo- nia from urine (A.O.A.C. 1984). Urine and feces were frozen at $-26^{\circ} \mathrm{C}$ until analysis. Composite diet and fecal samples were dried at $60^{\circ} \mathrm{C}$ for 48 hours, ground to pass through a $1 \mathrm{~mm}$ screen, dried at $105^{\circ} \mathrm{C}$, and ashed at $600^{\circ} \mathrm{C}$ to determine percent dry matter and organic matter, respectively. Nitrogen contents of prickly pear, feces, and urine were analyzed using standard micro-Kjeldahl procedures (Holechek et al. 1982). The fecal and urinary nitrogen content was subtracted from the nitrogen intake from the prickly pear to estimate nitrogen balance (Boutouba et al. 1990). Dry matter and organic matter digestibility of prickly pear were estimated using in vivo techniques and compared between prickly pear species (Holechek et al. 1982, Nunez-Hernandez et al. 1992).

Preliminary evidence suggested that nutrient content of prickly pear varied among seasons (Huston et al. 1981, Retamal et al. 1987). The metabolism trial was repeated in winter (December) to estimate differences in prickly pear quality between summer and winter. The same goats and protocol used in the summer trial were used in the winter trial.

\section{Previous Dietary Experiences}

In Experiment 2, 9 intact male and 9 female Boer-Spanish cross goats, 4-5 months of age, and weighing $20 \mathrm{~kg}$, were used to determine how experience with spineless prickly pear at weaning affected intake of singed prickly pear. Goats were placed in individual pens and allocated randomly to 1 of 2 treatments ( 9 goats/treatment). Four males were assigned to Treatment 1 with 5 females, and 5 males and 4 females were assigned to the other Treatment 2.

Treatments consisted of goats either naive or familiar with spineless prickly pear. All goats were raised in pens to control exposure to prickly pear before the test period, and all goats were naive to prickly pear before initiation of the study. The naive goats received only alfalfa pellets $\left(15 \mathrm{~g} \mathrm{~kg}^{-1} \mathrm{BW}\right)$ to meet maintenance requirements (NRC 1981). In addition to feeding alfalfa pellets at maintenance levels, experienced goats were also fed spineless prickly pear in excess for 1 hour daily until consumption leveled off ( 8 days). After the initial 8 days, all naive and experienced goats were fed singed prickly pear for 1 hour daily over 4 days, and intake was recorded daily. Prickly pear was harvested fresh daily, spines were singed, and pads were chopped into $5 \mathrm{~cm}$ wide strips to facilitate feeding. All goats continued to receive fresh water and $15 \mathrm{~g} \mathrm{~kg}^{-1} \mathrm{BW}$ of alfalfa daily throughout the study. 


\section{Feed and Prickly Pear Intake}

Experiment 3 began 14 days after the completion of Experiment 2. Goats from Experiment 2 were re-randomized to 1 of 3 treatments and placed in individual pens. An equal number of goats from Treatments 1 and 2 used in Experiment 2 were assigned to treatments for Experiment 3 to minimize the effect of previous experience with prickly pear. Goats were fed a maintenance diet of alfalfa pellets $\left(15 \mathrm{~g} \mathrm{~kg}^{-1} \mathrm{BW}\right)$ until the experiment began (14 days).

For this experiment, goats were allocated to 1 of 3 treatment groups. Treatment 1 was fed $10 \mathrm{~g} \mathrm{~kg}^{-1} \mathrm{BW}$ of alfalfa pellets daily to represent a diet below maintenance, Treatment 2 was fed $20 \mathrm{~g} \mathrm{~kg}^{-1} \mathrm{BW}$ of alfalfa pellets daily to represent a near maintenance diet, while Treatment 3 was fed $30 \mathrm{~g} \mathrm{~kg}^{-1} \mathrm{BW}$ of alfalfa pellets daily to exceed maintenance requirements. Freshly chopped singed prickly pear was fed to all 3 groups for 2 hours each morning before they were fed their pre-assigned alfalfa diet. Singed prickly pear intake was recorded daily over 5 days. The effects of basal diet feeding level on prickly pear consumption were compared among the 3 treatments.

\section{Statistical Analysis}

For each experiment, data were analyzed using analysis of variance (Hicks 1993). A 2 x 2 Latin square design (2 treatments and 2 periods) was used in Experiment 1. A nested design was used in all experiments with goats nested within treatments as replicates. Treatment (naive vs. familiar) served as the primary effect and sex as the secondary effect in Experiment 2. For Experiment 3, level of alfalfa intake was the primary effect and familiarity with prickly pear (from Exp. 2) was the secondary effect. Intake data for all 3 experiments were converted to $\mathrm{g} \mathrm{kg}^{-1}$ body weight (BW) on a dry matter basis to eliminate the effects of moisture content and body size on intake data. Data from Experiments 2 and 3 were analyzed using repeated measures analysis of variance because intake was measured for individual goats daily. Means were separated using least significant difference (LSD) when $\mathrm{P}<0.05$ (Gomez and Gomez 1984). Data were analyzed using the statistical computer package JMP (SAS 1994).

\section{Results}

\section{Metabolism Trial}

Goats readily consumed both prickly pear species. Goats consumed more $(\mathrm{P}<$ $0.05)$ spineless prickly pear on an as fed basis $\left(\mathrm{g} \mathrm{kg}^{-1} \mathrm{BW}\right)$, whereas dry matter intake was similar for both species of prickly pear (Table 1). Moisture content of prickly pear was high for both species and for both seasons (summer $95 \%$ and $90 \%$; winter $90 \%$ and $75 \%$ for spineless and spined prickly pear, respectively).

Digestibility varied between prickly pear species, but was similar between seasons. Digestibility of spineless prickly pear was greater than singed prickly pear for both dry matter $(\mathrm{P}<0.05)$ and organic matter $(\mathrm{P}<0.07)$ when data were combined across seasons (Table 1). Percent crude protein was also greater $(\mathrm{P}<0.05)$ for spineless prickly pear.

Nitrogen balance of goats did not differ when fed spined or spineless prickly pear (Table 1). Values were negative for both species in the summer $(-0.21 \mathrm{~g}$ vs $-0.42 \mathrm{~g}$ for spined and spineless, respectively). During the winter, nitrogen balance for goats consuming spined prickly pear were $0.36 \mathrm{~g}$ while goats consuming spineless prickly had a positive nitrogen balance of $4.0 \mathrm{~g}$.

\section{Previous Dietary Experiences}

During the 8-day familiarization period, goats ate on average $1.3 \mathrm{~g} \mathrm{~kg}^{-1} \mathrm{BW}$ DM of

Table 1. Mean nutritional parameters of spine (singed) and spineless prickly pear fed to goats for Experiment 1. Crude protein values were measured using the 2 outermost prickly pear cladodes.

\begin{tabular}{lcccr}
\hline \hline Parameter & Singed & SEM & Spineless & SEM \\
\hline Dry matter (\%) & 11.5 & & 23.7 & \\
Organic Matter (\%) & 74.0 & & 71.0 & \\
Intake, as fed basis $\left(\mathrm{g} \mathrm{kg}^{-1} \mathrm{BW}\right)$ & $91.0^{\mathrm{b}}$ & 4.1 & $154.0^{\mathrm{a}}$ & 3.9 \\
Dry matter intake $\left(\mathrm{g} \mathrm{kg}^{-1} \mathrm{BW}\right)$ & 14.0 & 1.3 & 12.0 & 1.3 \\
Fecal Output $\left(\mathrm{g} \mathrm{day}^{-1}\right)$ & $462.5^{\mathrm{a}}$ & 20.3 & $304.8^{\mathrm{b}}$ & 19.5 \\
Dry matter digestibility (\%) & $58.0^{\mathrm{b}}$ & 0.1 & $79.0^{\mathrm{a}}$ & 0.1 \\
Organic matter digestibility (\%) & $70.0^{\mathrm{b}}$ & 1.0 & $83.0^{\mathrm{a}}$ & 1.0 \\
Crude protein (\%) & $4.8^{\mathrm{b}}$ & 0.9 & $8.1^{\mathrm{a}}$ & 0.5 \\
Nitrogen balance (g/d) & 0.4 & 0.2 & 1.8 & 0.2 \\
\hline
\end{tabular}

${ }^{\mathrm{a}, \mathrm{b}}$ Means within rows with different superscripts differ ( Intake $\mathrm{P}<0.05 ; \mathrm{DMD}, \mathrm{P}<0.05 ; \mathrm{OMD}, \mathrm{P}<0.07 ; \mathrm{CP}, \mathrm{P}<$ $0.05)$ spineless prickly pear. Following initial exposure to spineless prickly pear, goats familiar with spineless prickly pear ate more $(\mathrm{P}<0.05)$ singed prickly pear than naive goats ( 3.1 vs. $1.0 \mathrm{~g} \mathrm{~kg}^{-1} \mathrm{BW}$ for goats familiar vs. naive to prickly pear). Intake of prickly pear differed $(\mathrm{P}<0.05)$ among days over the 4-days of feeding (Fig. 1). Nevertheless, familiar goats consistently ate more singed prickly pear than naive goats. Intake of prickly pear was similar $(\mathrm{P}>0.05)$ between males and females.

\section{Feed and Prickly Pear Intake}

Varying intake of alfalfa did not affect intake of singed prickly pear $(\mathrm{P}>0.05,3.2$ $\pm 0.6,3.3 \pm 0.6,3.5 \pm 1.3, \mathrm{~g} \mathrm{~kg}^{-1} \mathrm{BW}$ for below, near, and above maintenance, respectively). Goats familiar with spineless prickly pear in the previous experiment continued to eat more $(\mathrm{P}<0.08)$ singed prickly pear than naive goats $(4.2$ vs. $2.5 \mathrm{~g} \mathrm{~kg}^{-1} \mathrm{BW}$, for familiar vs. naive goats, respectively), regardless of the amount of alfalfa fed.

\section{Discussion}

\section{Nutritive Value of Prickly Pear}

Both species were moderately digestible (58-85\% DMD) and met nitrogen requirements for goats during the winter (Exp. 1). Goats readily consumed both species of prickly pear and consumed some prickly pear when another forage was fed to meet or exceed nutrient requirements (Exp. 3). We contend that prickly pear can be a viable alternative forage, especially when used as an emergency feed. Producers typically rely on prickly pear when other forage sources are depleted or dormant. Under these circumstances and given the negative nitrogen balance values during the summer trial (Exp. 1), protein supplementation may be required in addition to feeding prickly pear.

The prickly pear used in this study was only collected from 1 site and may vary nutritionally in other areas. Future studies should identify variations in nutritional value of prickly pear growing on different soil types and in different locations.

Consumption of spined prickly pear after singeing the spines suggests strongly that goats will consume prickly pear after prescribed burning. Prescribed burning or singeing spines with a propane torch would be required to reduce health hazards (Ueckert et al. 1990). In addition, livestock herbivory after burning should reduce prickly pear cover and density 


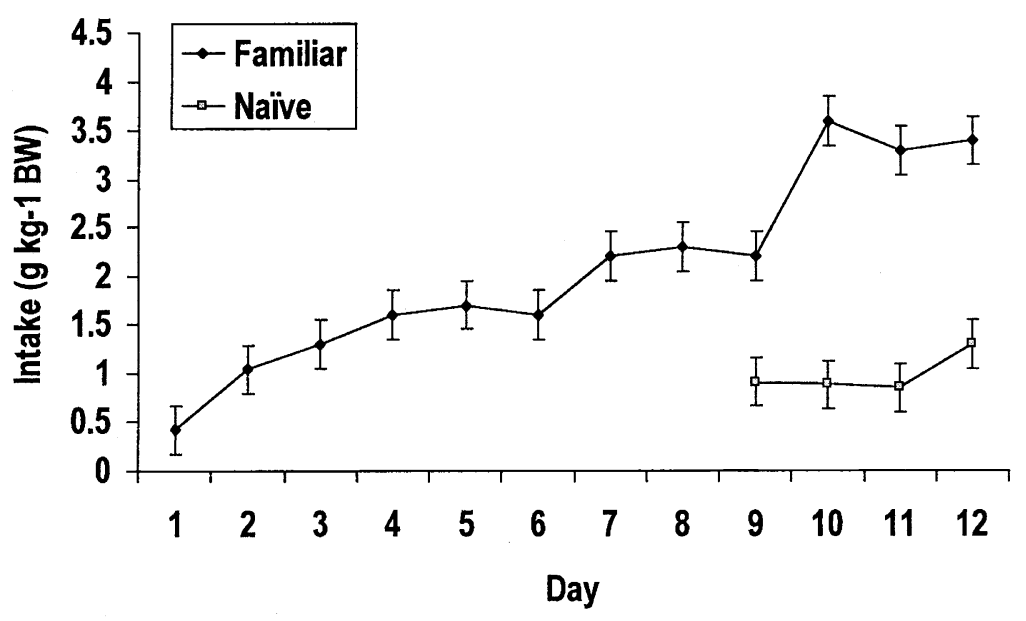

Fig. 1. Intake ( $\mathrm{g} \mathrm{kg}^{1} \mathrm{BW}$ ) of singed prickly pear by goats familiar or naive with spineless prickly pear over a 4 days (days 9 through 12) in Experiment 2. The first 8 days involved the familiarization period when experienced goats were fed spineless prickly pear. Average consumption of spineless prickly pear for the familiarization period was $1.3 \mathrm{~g} \mathrm{~kg}^{-1} \mathrm{BW}$ on dry basis.

given that this plant has a low tolerance to herbivory (Griffiths 1905). However, goat herbivory may need to occur quickly after burning before pads begin to spoil from heat damage (Ueckert pers. comm.).

Spineless prickly pear was more digestible and had a higher crude protein content than spined prickly pear. Thus, spineless prickly pear could serve as a palatable and nutritious alternative feed source for livestock and wildlife. Establishing spineless prickly pear can be highly successful, but requires at least 4 years to accumulate sufficient biomass (Turpin and Gil, 1928). Palatability of spineless prickly pear will necessitate fencing to reduce herbivory until establishment. Providing spineless prickly pear as a forage may be more cost effective than burning spined prickly pear when forage is limited because of the high cost of labor and propane fuel for burning.

Spineless prickly pear also could be established in food plots to serve as emergency forage for wildlife. Most forages grown on food plots for deer in central and western Texas were developed in areas that receive higher and more consistent precipitation, and most are not adapted to xeric climates. Because spineless prickly pear evolved in dry conditions, it should remain productive even during drought.

\section{Previous Dietary Experiences}

Previous foraging experiences improve acceptance, foraging skills, and may result in physiological adaptations to metabolize some toxins (Distel and Provenza 1991, Provenza 1994, Bisson et al. 2001). Foraging experiences are particularly important in the formation of dietary preferences when forages are nutritious and nonaversive (Villalba and Provenza 1997a, 1997b, 1997c, 1999). Prickly pear is moderately nutritious (Exp. 1) and lacks mechanical defenses after singeing. Feeding of spineless prickly pear increased consumption of singed prickly pear (Exp. 2), and this acceptance persisted (Exp. 3).

Weaning may be an important time for molding diet selection because of limited maternal influences on dietary habits (Hinch et al. 1987, Howery et al.1998). Conditioning the acceptance of prickly pear could be accomplished during weaning when replacement animals are separated from their dams and housed in separate facilities. Once goat kids acquire a preference for spineless prickly pear, the acceptance of singed prickly pear is easily attainable as observed in Experiment 2. As an alternative to growing and hand-feeding spineless prickly pear, producers could wean goat kids in a pasture after singeing prickly pear spines.

\section{Prickly Pear Intake}

Level of alfalfa intake did not affect intake of prickly pear in this study. Goats consumed prickly pear at a constant rate regardless of the level of intake of the basal diet. Goats may have consumed prickly pear because of an innate desire to consume a variety of foods. In another study, when lambs were offered 3 rations varying in nutrient quality (high, medium, and low), they consistently ate all 3 even though the high quality ration met all of their dietary requirements (Provenza et al.
1996). Food preferences change within meals often to less nutritious foods (Newman et al. 1994, Early and Provenza 1998) and ruminants prefer alternatives to forages they have consumed for several days (Newman et al. 1992, 1994, Ramos and Tennessen 1993) or even several hours (Parsons et al. 1994).

Prickly pear also may provide other essential nutrients that may be limited. Other studies have reported that livestock and wildlife often consume prickly pear even when forage quantity is not limited (Taylor et al. 1980, Fontenot et al. 1991). Phosphorous often is limited on central and western Texas rangelands. Ruminants occasionally consume atypical dietary items to rectify deficiencies (Provenza 1994).

\section{Implications}

Most southwestern livestock producers consider spined prickly a hindrance to forage production; spined prickly pear has increased in cover in the last 100 years because of overgrazing and the lack of fire. Controlling spined prickly pear in the southwestern U.S. is often not practical because of economic restraints, its use as emergency feed during droughts, and its importance for wildlife habitat.

Spineless prickly pear has the potential as an alternative forage for goats or other domestic livestock or deer. Nutritionally, it yields enough protein to meet protein requirements of goats under some levels or stages of production. In addition, for most current management systems, spined prickly pear is an unused forage source. However, combining prescribed burning with goat herbivory would allow prickly pear to be used as a forage resource without jeopardizing the animal health and reduce prickly pear cover and density.

\section{Literature Cited}

A.O.A.C. 1984. Official Methods of Analysis $\left(14^{\text {th }}\right.$ Ed.). Association of Official Analytical Chemists, Washington D.C.

Bement, R.E. 1969. Plains pricklypear: relation to grazing intensity and blue grama yield on central Great Plains. J. Range Manage. 21:83-86.

Bisson, M.G., C.B. Scott, C.A. Taylor, Jr., and R.A. Moen. 2001. Activated charcoal and experience affect intake of juniper by goats. J. Range Manage. 54:274-278.

Boutouba, A., J.L. Holechek, M.L. Galyean, G. Nunez-Hernandez, J.D. Wallace, and M. Cardenas. 1990. Influence of two native shrubs on goat nitrogen status. J. Range Manage. 43:530-534. 
Brutsch, M.O. and H.G. Zimmerman. 1993. The prickly pear (Opuntia ficus-indica [Cactaceae]) in South Africa: utilization of the naturalized weed and of cultivated plants. Econ. Bot. 47:154-162.

Distel, R.A. and F.D. Provenza. 1991 Experience early in life affects voluntary intake of blackbrush by goats. J. Chem. Ecol. 17:431-450.

Early, D.M. and F.D. Provenza. 1998. Food flavor and nutritional characteristics alter dynamics of food preference in lambs. J. Anim. Sci. 76:728-734.

Fontenot, N.J., G.R. Engdahl, G.L. Holland, and W.H. Schacht 1991. Seasonal diet selection of white-tailed deer (Odocoileus virginianus) in relation to forage availability in west central Texas. MIR Prog. Rep. No. R-5:8-9.

Garcia de Cortazar, V. and P.S. Nobel. 1992. Biomass and fruit production for the prickly pear cactus, Opuntia fiscus-indica. J. Amer. Soc. Hort. Sci. 117:558-562.

Gomez, K.A. and A.A. Gomez. 1984. Statistical Procedures for Agricultural Research. pp. 187-207. John Wiley and Sons, New York.

Griffiths, D. 1905. The prickly pear and other cacti as food for stock. USDA Bureau of Plant Industries Bull. 74:46.

Hanselka, C.W. and J.C. Paschal. 1991. Prickly pear cactus: an important rangeland resource. In: Progress Report, pp. 141-143. Texas Agr. Exp. Sta., U.S.A.

Hanselka, C.W., R.Q. Landers, and J.C. Paschal. 1993. Prickly pear: friend or foe. Texas Agri. Ext. Ser. at Corpus Christi. Technical Rept. B-5046.

Hicks, C.R. 1993. Fundamental Concepts in the Design of Experiments. p. 201. Saunders College Publishing, New York.

Hinch, G.N., E. Lecrivain, J.J. Lynch, and R.L. Elwin. 1987. Changes in maternalyoung associations with increasing age of lambs. Appl. Anim. Behav. Sci. 17:305-318.

Howery, L.D., F.D. Provenza, R.E. Banner, and C.B. Scott. 1998. Social and environmental factors influence cattle distribution on rangeland. Appl. Anim. Behav. Sci. 55:231-244

Holechek, J.L., M. Vavra, and R.D. Pieper. 1982. Methods of determining the nutritive quality of range ruminant diets: a review. J. Anim. Sci. 53:291-302.

Huston, J.E., B.S. Rector, W.C. Ellis, M.L. Allen. 1986. Dynamics of digestion in cattle, sheep, goats and deer. J. Anim. Sci. 62:208-215.

Huston, J.E., B.S. Rector, L.B. Merrill, and B.S. Engdahl. 1981. Nutritional Value of Range Plants in the Edwards Plateau Region of Texas. Texas Agr. Exp. Sta. Bull. B-1357.

Lehman, V.W. 1969. Forgotten legions, sheep in the Rio Grande Plains of Texas. Texas Western Press. U.S.A.: Univ. of Texas at El Paso. 226 pp.

Maltsberger, W.A. 1989. Prickly pear cactus an unsung blessing of the Rio Grande Plains. pp. 19-30. In: C.W. Hanselka and J.C. Paschal (eds.) Developing Prickly Pear as a
Forage, Fruit, and Vegetable Resource. Proc. of Conference July 14, 1989. Kingsville, Tex. Tex. Agr. Ext. Serv. College Station.

Mayeux, H.S., Jr. and H. B. Johnson. 1989. Absorption and translocation of picloram by Lindheimer pricklypear (Opuntia lindheimeri). Weed Sci. 37:161-166.

Newman, J.A., A.J. Parsons, and A. Harvey. 1992. Not all sheep prefer clover: diet selection revisited. J. Agr. Sci. Cambridge. 119:275-283.

Newman, J.A., P.D. Penning, A.J. Parsons, A. Harvey, and R.J. Orr. 1994. Fasting affects intake behaviour and diet preference of grazing sheep. Anim. Behav. 47:185-193.

NRC. 1981. Nutrient Requirements of Goats Angora, Dairy, and Meat Goats in Temperate and Tropical Countries. National Academy Press, Wash. D.C

Nunez-Hernandez, G., J.L. Holechek, D. Arthun, A. Tembo, J.D. Wallace, M.L. Galyean, M. Cardenas, R. Valdez. 1992. Evaluation of fecal indicators for assessing energy and nitrogen status of cattle and goats. J. Range Manage. 45:143-147.

Parsons, A.J., J.A. Newman, P.D. Penning, A. Harvey, and R.J. Orr. 1994. Diet preference of sheep: effect of recent diet, physiological state and species abundance. J. Anim. Ecol. 63:465-478.

Provenza, F.D. 1994. Ontogeny and social transmission of food selection in domesticat ed ruminants. In press In:P. Valsecchi and B.G. Galef (eds.) Ontogeny and social transmission of food preferences in mammals: Basic and Applied Research. Harwood Acad. Press, London.

Provenza, F.D. 1995. Postingestive feedback as an elementary determinant of food preferences and intake in ruminants. J. Range Manage. 48:2-17.

Provenza, F.D., C.B. Scott, T.S. Phy, and J.J. Lynch. 1996. Preference of sheep for foods varying in flavors and nutrients. J. Anim. Sci. 74:2355-2361.

Ramos, A. and T. Tennessen. 1993. A note on the effect of dietary variety on food intake of cattle. Anim. Prod. 57:323-325.

Retamal, N., J.M. Duran, and J. Fernandez. 1987. Seasonal variations of chemical composition of prickly pear (Opuntia ficus-indica (L.) Miller). J. Sci. Food Agr. 38:303-311.

SAS. 1994. JMP User's Guide, Version 3.1. SAS Institute Inc., N.C.

Taylor, C.A., M.M. Kothmann, L.B. Merrill, and D. Elledge. 1980. Diet selection by cattle under high-intensity low-frequency, short duration, and Merrill grazing systems. J. Range Mange. 6:428-434.

Teles, F.F.F., J.W. Stull, W.H. Brown, and F.M. Whitney. 1984. Amino and organic acids of the prickly pear cactus (Opuntia ficus-indica L.). J. Sci. Food Agr. 35:421425.

Turpin, H.W., and G.A. Gill. 1928. Insurance against drought. So. Africa Dept. Agr. Bull. 36:32.

Ueckert, D.N. 1997. Pricklypear ecology. Proc. of Brush Sculptors Symposium. pp. 35-38. Tex Agri. Exp. Sta. and Tex Agr. Ext. Ser. San Angelo.
Ueckert, D.N., J.L. Petersen, R.L. Potter, J.D. Whipple and M.W. Wagner. 1988. Managing pricklypear with herbicides and fire. Texas Agr. Exp. Sta. Prog. Rep. Pr4570.

Ueckert, D.N., C.W. Livingston, Jr., J.E. Huston, C.S. Menzies, R.K Dusek, J.L. Petersen, and B.K. Lawrence. 1990. Range and sheep management for reducing pearmouth and other pricklypear-related health problems in sheep flocks. Sheep and Goat, Wool and Mohair, Res. Report. Tex Agr. Exp. Sta., San Angelo, Tex.

Villalba, J.J. and F.D. Provenza. 1997a. Preference for wheat straw by lambs conditioned with intraruminal infusions of starch. Br. J. Nutr. 77:287-297.

Villalba, J.J. and F.D. Provenza. 1997b. Preference for flavored wheat straw by lambs conditioned with intraruminal infusions of acetate and propionate. J. Anim. Sci. 75:2905-2914.

Villalba, J.J. and F.D. Provenza. 1997c. Preference for flavoured foods by lambs conditioned with intraruminal administration of nitrogen. Br. J. Nutr. 78:545-561.

Villalba, J.J. and F.D. Provenza. 1999 Effects of food structure and nutritional quality and animal nutritional state on intake behaviour and food preferences of sheep. Appl. Anim. Behav. Sci. 63:145-163. 